\title{
Analysts seek proof of military precision
}

Geoff Brumfiel, Washington

Amid all the questions surrounding the second Gulf War, one thing is reasonably certain: great claims will be made for the new generation of guided weapons systems that the Pentagon is deploying in Iraq. For a group of sceptical physicists and defence experts, that represents a special challenge.

At outfits such as the Security Studies Program at the Massachusetts Institute of Technology (MIT), these experts are gearing up to second-guess the Pentagon's assessment of its systems. It's a painstaking task, given the paucity of information that will fall into the public domain. But it's also one of considerable political significance. The US and British governments have stated that they want to defeat Saddam Hussein while keeping civilian casualties to a minimum, and without destroying Iraq's economic infrastructure. Meeting those goals will depend crucially on the military's precision munitions working as advertised to hit accurately identified targets.

Defence analysts will also be looking at the performance of a new generation of Patriot missile interceptors, which are close cousins of the Pentagon's ballistic-missile defence system. After the last Gulf War, it took an MIT team led by physicists George Lewis and Theodore Postol two years to debunk the Pentagon's claim that the older Patriot missile system successfully intercepted most of Iraq's Scud missiles. This time, the independent and unwanted assessors are expecting more data from the larger number of reporters and film crews that the US-led coalition is letting in to cover the war. But they also

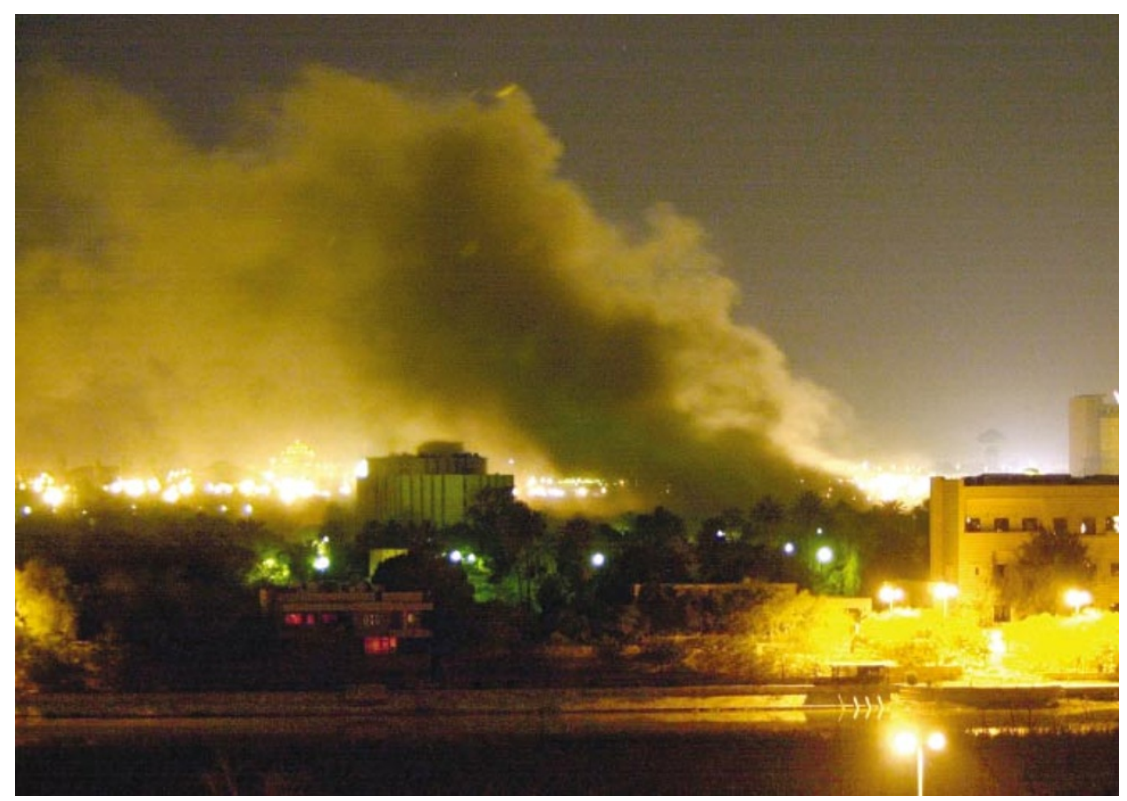

Shock and awe: independent verification of the accuracy of the US bombardment may be hard to obtain.

fear that a clampdown on other public data could make their task more difficult. "I'm going to be looking at whatever I can get data on," says Lewis.

With Saddam Hussein's ruling party well ensconced in central Baghdad, the coalition's goal depends on 'smart' weapons finding their targets with pinpoint accuracy. Smart bombs generally fall into two categories, guided either by lasers or satellite. From a technical standpoint, the ability of these bombs to strike close to a prescribed target is reasonably well established, according to William Arkin, a
Washington-based defence analyst.

What is far less clear is the quality of intelligence given to the weapons before they are fired, says Barry Posen, a professor of political science at MIT. During the 1999 conflict in Kosovo, the Pentagon claimed that precision munitions destroyed hundreds of Serbian tanks and armoured vehicles. But under closer scrutiny, it became clear that many of the weapons had hit decoy targets. "I think the verified claims in the end were no more than a few dozen," says Posen.

Press reports will be about the only way to

\section{Inspectors face uphill struggle in search for banned weapons in Iraq}

Natasha McDowell

A second invasion of Iraq may soon be under way - this time by military teams of technical experts trained to identify and destroy weapons of mass destruction (WMD).

According to the US Department of Defense, 'assessment teams' will examine a prioritized list of suspected WMD sites. Where they find suggestions of suspicious activity, 'mobile exploitation teams' will be called in to take samples and conduct further analyses in sophisticated mobile laboratories. Finally, 'disablement teams' will be deployed to destroy any biological or chemical weapons that are found.

The Pentagon declines to comment in detail on the technology at the teams' disposal. But the assessment teams are likely to be equipped with portable devices that can rapidly scan for the presence of banned weapons. These include hand-held chemical-agent monitors, which ionize air samples and then examine the mobility of the clusters of ions that are formed. Another portable device can analyse chemicals inside sealed containers by recording the $\gamma$-ray spectrum given off when the contents are bombarded with neutrons.

But experts warn that portable devices which may also be carried by frontline troops can give false positive results. This happened several times during the first Gulf War, says Kenneth Boutin, a researcher at VERTIC, a nongovernmental organization in London interested in the verification of arms-control agreements. As Nature went to press, the dubious reliability of initial reports had already been underlined by a claim on 23 March - later dismissed as "premature" by Pentagon sources - that US troops had found a chemical-weapons facility near Najaf, some 160 kilometres south of Baghdad.

The Pentagon says that its teams may seek help from members of the United Nations Monitoring, Verification and Inspection Commission (UNMOVIC), the inspection body that until recently was operating in Iraq. "We envisage, at the appropriate time, augmenting our teams in theatre with former UN inspectors," a Pentagon spokesman told Nature. According to some reports, several UNMOVIC inspectors have already been approached.

But given that the political justification for the war depends heavily on the assertion that Iraq has continued to possess WMDs in defiance of UN resolutions, the international community may want to see verification of any positive results by laboratories entirely independent of the US and British governments. "Independent verification is vital," says Julian Perry Robinson of the University of Sussex in Brighton, director of the Harvard Sussex Program, which aims to inform public policy on chemical and biological warfare. 
assess the military's latest intelligencegathering technologies, says Philip Coyle, a senior adviser for the Center for Defense Information, who spent seven years as director of the Pentagon's Operational Test and Evaluation Directorate. By scrutinizing media coverage and the defence department's public statements, Coyle hopes to study the success of technologies aimed at telling smart bombs where to strike, such as the new computerized command and control systems, and unmanned aerial vehicles.

Postol and Lewis, meanwhile, will be seeking clues about the performance of the Patriot missile interceptor. After the first Gulf War, the MIT team conducted a frameby-frame analysis of 33 Patriot intercept attempts to determine the altitude, speed and outcome of each engagement. "We were able to get an enormous amount of information from the footage," says Postol. Their analysis showed that at least a third of the Patriots fired during the first Gulf War failed to destroy a Scud missile - demolishing the army's initial claims of a $96 \%$ success rate for the system.

This time the MIT researchers plan to videotape hours of news coverage to track the latest generation of Patriot missiles, known as the Patriot Advanced Capability-3 (PAC-3). Unlike the original Patriots, which used explosives to blow up incoming missiles, the PAC-3 destroys warheads by the sheer force of its collision with them. This 'hit-to-kill' technology is also the basis of the first-generation US ballistic-missile defence system being built in Alaska, heightening interest in the system's performance. Already, the army's central command says that four Iraqi missiles have been intercepted by the PAC-3 system.

Some analysts complain that, even as the Pentagon opens up the battlefield to the press — assigning some 500 reporters to US military units - it is shutting down other data sources. Earlier this year, for example, the US administration began classifying missiledefence test data (see Nature 417, 777; 2002). John Pike, head of Washington-based Globalsecurity.org, says that he used to use commercial satellite images to analyse military activity, but when US troops entered Afghanistan in 2001, the United States bought all of the images so that no one could access them. It is unclear whether the administration will follow a similar course during the present conflict with Iraq, he says.

"The data are getting worse and worse," says Arkin. Nonetheless, Lewis says that his team will continue to scour hours of news coverage to find hints about how weapons are performing. "It's more important than ever to do this because this administration has become so secretive," he says.

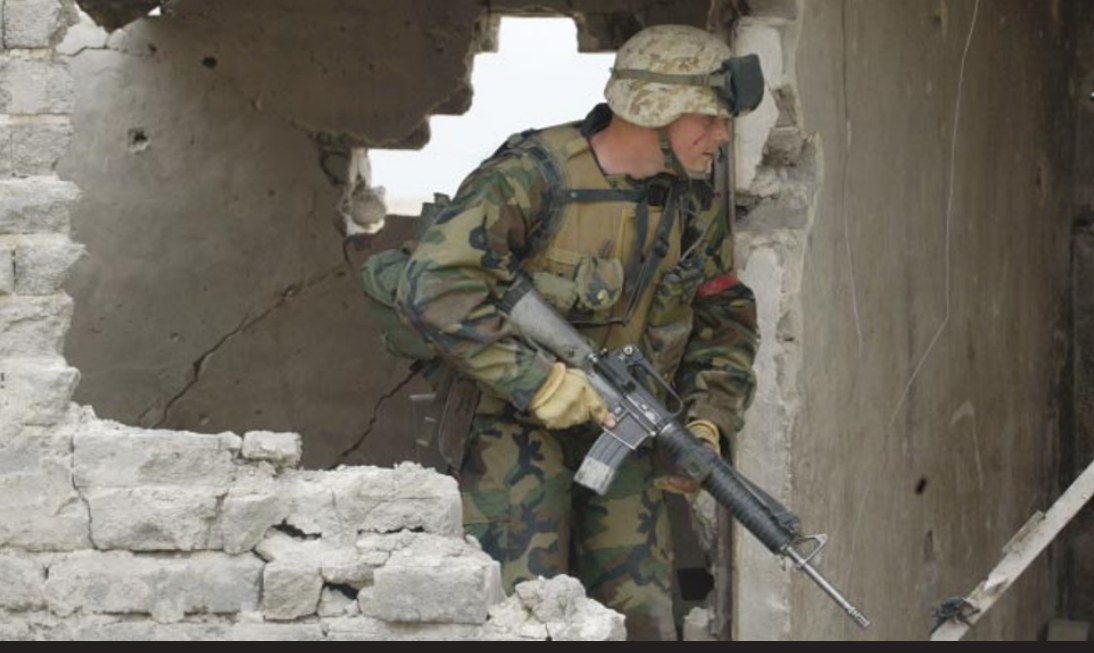

The US may face accusations of hypocrisy if it deploys riot-control agents during street fighting.

\section{Critics slam US over plans to use riot-control chemicals in the Gulf}

\section{Jonathan Knight, San Francisco}

As thousands of US troops poured into Iraq last week, an argument was breaking out back home about their possible readiness to use tear-gas or even chemical calming agents during the conflict.

Some military experts argue that riotcontrol agents could help to reduce enemy and civilian casualties, particularly if urban warfare breaks out in the streets of Baghdad. But others contend that the use of chemical agents would violate the 1997 Chemical Weapons Convention (CWC).

These objections were delivered to President George W. Bush and British Prime Minister Tony Blair in a 20 March letter from interest groups including the Union of Concerned Scientists, and Physicians for Social Responsibility. The letter urged the two leaders to outlaw the use of riot-control agents or calmatives in Iraq.

The topic first surfaced on 5 February, when US defence secretary Donald Rumsfeld told the House Armed Services Committee that he was looking for ways to allow commanders in the field to use riotcontrol agents, and implied he would seek presidential approval for such measures.

The United States has a legal framework that could permit such action. After the Vietnam War, the then President, Gerald Ford, ruled that chemical riot-control agents, such as tear-gas, could be used in certain circumstances but only with permission from the White House. One such situation would be to disperse civilians that enemy troops were using as a human shield.

The White House has not said whether such permission has been sought for the current conflict. The Pentagon confirms that chemical smoke and pepper spray have been used in previous conflicts, but declines to say what has been supplied to units in Iraq.

Some observers contend that US forces are carrying more dangerous calmative agents, comparable to the gas used to end a siege in a Moscow theatre last October that resulted in the deaths of over 120 hostages and 41 hostage-takers. "We can document Pentagon research on these agents," says Edward Hammond of the Sunshine Project, a pressure group based in Austin, Texas, that opposes the development of chemical weapons. "I think they are chomping at the bit to use these things," he says.

But the Pentagon denies that such a research programme exists. The Department of Defense "is not pursuing any chemically or biologically based incapacitating agents", says a Pentagon spokesman.

Experts also disagree on whether the use of riot-control agents would violate the CWC. The document's wording covers chemicals that cause "temporary incapacitation", but its real targets are strongly toxic substances such as nerve gases, says Jim Lewis, a senior fellow at the Center for Strategic and International Studies in Washington DC. "It was poor drafting," he says. "As it stands, it includes the mace on your key chain."

Furthermore, proponents of calmative agents argue that non-lethal gases save lives. If enemy soldiers are hiding in a building with civilians, for example, it is safer to drive everyone out than to go charging in, they point out.

Objectors counter that the Moscow incident showed that calmatives can be lethal (see Nature 420, 7; 2002). And some take exception to the use of milder agents such as tear-gas. Mark Wheelis, a microbiologist at the University of California, Davis, says that many countries would see the use of tear-gas to disarm Iraq of chemical weapons as hypocritical. "If the United States uses riotcontrol agents, most of the world would consider it a violation of the CWC," he says. 